\title{
Profile of patients receiving medical care at a reference, support, and treatment center for psoriasis patients at a university hospital*
}

\author{
Túlio Germano Machado Cordeiro Júnior ${ }^{1}$ \\ Esther Bastos Palitot ${ }^{1}$ \\ Sandra Rodrigues Mascarenhas ${ }^{1}$
}

\author{
Bruno D' Paula Andrade ${ }^{1}$ \\ Márcia Regina Piuvezam ${ }^{1}$
}

DOI: http://dx.doi.org/10.1590/abd1806-4841.201644945

\begin{abstract}
Psoriasis is a chronic, inflammatory, immune-mediated disease affecting 1-3\% of the population worldwide. This work seeks to draw a profile of patients with psoriasis, analyzing socioeconomic, anthropometric, and clinical aspects. For this, medical records from 81 individuals who received medical care in a university hospital in 2014 were consulted. It was observed that the patients were mostly dark-skinned black adult men, with a low education level and a low income, who were sedentary, former smokers, obese, with an increase in waist circumference, and who did not consume alcohol. Psoriasis vulgaris predominated, beginning mainly on the scalp, hands, and feet. In addition, many presented some type of associated comorbidity and had relatives with psoriasis.
\end{abstract}

Keywords: Comorbidity; Dermatology; Health profile; Psoriasis

Psoriasis is a chronic, inflammatory, erythematous scaly, immune-mediated disease, which occurs universally, affecting men and women equally in $1-3 \%$ of the population worldwide. ${ }^{1,2}$

The physiopathology involves immune system, genetic and environmental components. ${ }^{1,2}$ It is characterized by the expansion and activation of Th1, Th17, Th22, and T-cells, with the production of the associated cytokines, such as Interferon, the tumor necrosis factor (TNF), interleukin 17 (IL17), and IL22 on the skin., Factors such as traumas, acute and intense exposure to sunlight, infections, certain drugs, psychogenic and emotional factors, smoking, alcohol, and endocrine factors may trigger or worsen psoriatic lesions.

For this prospective and observational study, 81 patients treated at a psoriasis reference center in a university hospital were selected. The project was approved by the Human Research Ethics Committee. The following data were verified: gender, skin color, age group, education level, income level, per capita income, smoking, alcoholism, sedentary lifestyle, abdominal circumference, Body Mass Index (BMI), type of psoriasis, sites and age when the lesions began, presence of comorbidities, existence of relatives with psoriasis, and occurrence of psoriatic arthritis.
The majority of people, 75 (92.6\%), were 18 years of age or older. In addition, in 31 cases (38.6\%), the first lesions appeared earlier than or at 18 years of age, affecting both genders equally (Table 1 ).

Data showed that 45 patients $(55.6 \%)$ were dark-skinned, $27(33.3 \%)$ were white, and $9(11.1 \%)$ were black (Table 1$)$. This result is in disagreement with the majority of the literature, in which occurrences in people with white skin have been more prevalent, as psoriasis tends to be rare in black, indigenous, and Asian people.,

It was determined that, predominantly, $60(74.1 \%)$ of the people were paid under the minimum wage, and $25(30.9 \%)$ had not completed elementary school, thus reflecting the socioeconomic status of most of the Brazilian Unified Health System (SUS) users (Table 1).

Studies show that smoking and alcohol consumption, in addition to being risk and worsening factors of the disease, also reduce patient response to treatment. ${ }^{6,7}$ In this sense, the majority, 44 individuals (54.3\%), consisted of ex-smokers, and 41 (50.6\%) did not consume alcohol (Table 1).

Received on 18.07.2015

Approved by the Advisory Board and accepted for publication on 11.10.2015

* Work conducted at the Reference Center for Support and Treatment of Psoriasis Patients at the Hospital Universitário Lauro Wanderley - Universidade Federal da Paraíba (UFPB), João Pessoa, Paraíba, Brazil.

Financial Support: None.

Conflict of Interest: None.

1 Universidade Federal da Paraíba (HULW-UFPB), João Pessoa, PB, Brazil.. 
In this study, 58 patients $(71.6 \%)$ stated that they do not exercise (Table 1). It is known that regular exercise, at moderate intensity, improves some risk factors (mental health, vitality, body composition, sleeping), in addition to helping insulin and psoriasis control. ${ }^{8}$

It has been reported that psoriasis favors weight increase and obesity. ${ }^{1,8,9}$ Studies show a relation between obesity and chronic inflammation, in which the fatty tissue is part of the immune system and the number of adipocytes is proportional to that of macrophages. An association can be observed between high levels of TNFa, IL6, IL17, leptin, and C-reactive protein, and increases in BMI, which contribute to alterations in insulin biochemical pathways, leading to insulin resistance, and contributes to the increase in lipid levels, triglycerides, type II diabetes, and cardiovascular diseases. The inflammatory state, in obese individuals, is also related to the development or worsening of psoriasis. ${ }^{3,9}$

TAble 1: Psoriasis patients' socioeconomic characteristics and habits ( $\mathrm{n}=81)$. João Pessoa (PB), Brazil, 2014

\begin{tabular}{|c|c|c|}
\hline Variable & $\begin{array}{l}\text { Absolute } \\
\text { frequency (n) }\end{array}$ & $\begin{array}{l}\text { Relative } \\
\text { frequency }(\%)\end{array}$ \\
\hline \multicolumn{3}{|l|}{ Gender } \\
\hline Male & 43 & 53.1 \\
\hline Female & 38 & 46.9 \\
\hline \multicolumn{3}{|l|}{ Skin color } \\
\hline White & 27 & 33.3 \\
\hline Dark-skinned & 45 & 55.6 \\
\hline Black & 9 & 11.1 \\
\hline \multicolumn{3}{|l|}{ Age group } \\
\hline $\begin{array}{l}\text { Children } \\
\text { (0-11 years of age) }\end{array}$ & 4 & 4.9 \\
\hline $\begin{array}{l}\text { Adolescents } \\
\text { (12-18 years of age) }\end{array}$ & 2 & 2.5 \\
\hline $\begin{array}{l}\text { Adults } \\
\text { (19-59 years of age) }\end{array}$ & 61 & 75.3 \\
\hline $\begin{array}{l}\text { Senior citizens } \\
(>\text { or }=60 \text { years of age) }\end{array}$ & 14 & 17.3 \\
\hline \multicolumn{3}{|l|}{ Education level } \\
\hline Illiterate & 10 & 12.3 \\
\hline Elementary school - incomplete & te 25 & 30.9 \\
\hline Elementary school - complete & 14 & 17.3 \\
\hline High school - incomplete & 2 & 2.5 \\
\hline High school - complete & 21 & 25.9 \\
\hline College degree - incomplete & 1 & 1.2 \\
\hline College degree - complete & 8 & 9.9 \\
\hline \multicolumn{3}{|l|}{ Per capita income } \\
\hline Up to minimum wage & 60 & 74.1 \\
\hline 1 to 3 times minimum wages & 18 & 22.2 \\
\hline Over 3 times minimum wages & 3 & 3.7 \\
\hline \multicolumn{3}{|l|}{ Smoking } \\
\hline Smokers & 14 & 17.3 \\
\hline Non-smokers & 44 & 54.3 \\
\hline Ex-smokers & 23 & 28.4 \\
\hline \multicolumn{3}{|l|}{ Alcohol consumption } \\
\hline Consumes alcohol & 22 & 27.2 \\
\hline Does not consume alcohol & 41 & 50.6 \\
\hline No longer consumes alcohol & 18 & 22.2 \\
\hline \multicolumn{3}{|l|}{ Exercising } \\
\hline Exercises & 23 & $28.4 \%$ \\
\hline Does not exercise & 58 & $71.6 \%$ \\
\hline Total & 81 & $100 \%$ \\
\hline
\end{tabular}

In this aspect, the research revealed that 26 people $(32.1 \%)$ were overweight, $33(40.7 \%)$ were obese, and $48(59.3 \%)$ presented a high abdominal circumference (Table 2).

Psoriasis type II more commonly occurs among family members, most often associated with an early onset of the dis-

TABLE 2: Anthropometric measurements and clinical characteristics of psoriasis patients $(\mathrm{n}=81)$. João Pessoa (PB), Brazil, 2014

\begin{tabular}{|c|c|c|}
\hline Variable & $\begin{array}{l}\text { Absolute } \\
\text { frequency (n) }\end{array}$ & $\begin{array}{l}\text { Relative } \\
\text { frequency (\%) }\end{array}$ \\
\hline \multicolumn{3}{|l|}{ BMI (kg/m2)* } \\
\hline $\begin{array}{l}\text { Low weight } \\
\left(<18.5 \mathrm{~kg} / \mathrm{m}^{2}\right)\end{array}$ & 4 & 4.9 \\
\hline $\begin{array}{l}\text { Normal weight } \\
\left(18.5-24.9 \mathrm{~kg} / \mathrm{m}^{2}\right)\end{array}$ & 18 & 22.2 \\
\hline $\begin{array}{l}\text { Pre-obese } \\
\left(25.0-29.9 \mathrm{~kg} / \mathrm{m}^{2}\right)\end{array}$ & 26 & 32.1 \\
\hline $\begin{array}{l}\text { Grade I obesity } \\
\left(30.0-34.9 \mathrm{~kg} / \mathrm{m}^{2}\right)\end{array}$ & 11 & 13.6 \\
\hline $\begin{array}{l}\text { Grade II obesity } \\
\left(35.0-39.9 \mathrm{~kg} / \mathrm{m}^{2}\right)\end{array}$ & 18 & 22.2 \\
\hline $\begin{array}{l}\text { Grade III obesity } \\
\left(\geq 40 \mathrm{~kg} / \mathrm{m}^{2}\right)\end{array}$ & 4 & 4.9 \\
\hline \multicolumn{3}{|l|}{$\begin{array}{l}\text { Abdominal } \\
\text { circumference }(\mathrm{cm}) * *\end{array}$} \\
\hline \multicolumn{3}{|l|}{ Males } \\
\hline$>90 \mathrm{~cm}$ & 13 & 30.2 \\
\hline$<90 \mathrm{~cm}$ & 30 & 69.3 \\
\hline \multicolumn{3}{|l|}{ Females } \\
\hline$>80 \mathrm{~cm}$ & 35 & 92.1 \\
\hline$<80 \mathrm{~cm}$ & 3 & 7.9 \\
\hline \multicolumn{3}{|l|}{ Comorbidities } \\
\hline Diabetes & 18 & 22.2 \\
\hline Dyslipidemias & 14 & 17.3 \\
\hline Hypertension & 25 & 30.9 \\
\hline $\begin{array}{l}\text { Atopies (asthma, } \\
\text { rhinitis, or atopic dermatitis) }\end{array}$ & 10 & 12.3 \\
\hline Cardiovascular diseases & 1 & 1.2 \\
\hline Eye diseases & 4 & 4.9 \\
\hline Absence of comorbidities & 13 & 16 \\
\hline \multicolumn{3}{|l|}{ Psoriasis type } \\
\hline Vulgaris & 76 & 83.8 \\
\hline Inverse & 0 & 0 \\
\hline Erythrodermic & 1 & 1.2 \\
\hline Guttate & 0 & 0 \\
\hline Pustular & 4 & 4.8 \\
\hline \multicolumn{3}{|l|}{ Time of onset of disease } \\
\hline Up to 18 years of age & 31 & 38.6 \\
\hline After 18 years of age & 50 & 61.4 \\
\hline \multicolumn{3}{|l|}{ Lesion sites } \\
\hline Hand/foot & 23 & 28.4 \\
\hline Elbow/knee & 12 & 14.8 \\
\hline Back area & 4 & 4.9 \\
\hline Abdominal area & 5 & 6.2 \\
\hline Scalp & 26 & 32.1 \\
\hline Others & 11 & 13.6 \\
\hline Total & 81 & $100 \%$ \\
\hline
\end{tabular}


ease. ${ }^{1,2}$ In this sense, among the 6 patients under 18 years of age, half had a family member who was a psoriasis patient; and among the 75 patients of above 18 years of age, only 28 (37.3\%) reported having a family member with psoriasis.

As regards the clinical form of psoriasis, 76 patients (93.8\%) presented psoriasis vulgaris, followed by 4 patients (4.9\%) with pustular psoriasis (Table 2). Data from the literature indicate that psoriasis vulgaris was the most common disease, affecting approximately $80 \%$ to $90 \%$ of the patients. ${ }^{1}$ Low prevalence of erythrodermal form of the disease in this study is justifiable, as it refers to outpatient services, whereas for specific cases of erythrodermic psoriasis, inpatient treatment would be required.

Records showed that 53 people $(65.4 \%)$ presented psoriatic arthritis. These high numbers are most likely due to the multidisciplinary nature of this Center, where Dermatology and Rheumatology work together, enabling more diagnoses.

Lesions appear more frequently in portions of the body normally covered by clothes or protected by hair, that is, areas less exposed to ultraviolet radiation. ${ }^{2,8}$ This study detected that in 26 patients $(32.1 \%)$ lesions began mainly on the scalp, whereas in 23 patients $(28.4 \%)$ they appeared first in the hands and feet.

\section{REFERENCES}

1. Sociedade Brasileira de Dermatologia. Consenso Brasileiro de Psoríase 2012: guia de avaliação e tratamento Sociedade Brasileira de Dermatologia. 2.ed. Rio de Janeiro: Sociedade Brasileira de Dermatologia; 2012.

2. Kimball AB, Gieler U, Linder D, Sampogna F, Warren RB, Augustin M. Psoriasis: is the impairment to a patient's life cumulative?.Cumulative life course impairment in psoriasis. 2010; 989-1004

3. Davidovici BB, Sattar N, Prinz J, Puig L, Emery P, Barker JN, et al. Psoriasis and Systemic Inflammatory Diseases: Potential Mechanistic Links between Skin Disease and Co-Morbid Conditions. J Invest Dermatol. 2010;130:1785-96.

4. Andrade LE, Andrade LM. Imunopatogênese da psoríase: revisando conceitos. AnBrasDermatol. $2011 ; 86: 1151-8$

5. Flambó, P. A. D. G. (2004/2006). Avaliação do bem-estar psicológico em sujeitos com Psoríase. Tese de Mestrado em Psicologia da Saúde apresentada ao Instituto Superior de Psicologia Aplicada (ISPA), Lisboa

6. Behnam SM, Behnam SE, Koo JY.Smoking and psoriasis.Skinmed. 2005;4:174-6.

7. Poikolainen K, Reunala T, Karvonen J, Lauharanta J, Kärkkäinen P. Alcohol intake: a risk factor for psoriasis in young and middle aged men? BMJ. 1990;300:780-3.

8. Arruda, LHF, Arruda, ACBB; Lima, RG, Suehiro RM. Psoríase e comorbidades. RevBrasMed. 2011;68:11- 20

9. Duarte GV, Follador I, Cavalheiro CMA, Silva TS, Oliveira MFSP. Psoríase e obesidade: revisão de literatura e recomendações no manejo. An Bras Dermatol. 2010;85:355-60.
Literature shows that the presence of systemic diseases related to psoriasis is frequent. ${ }^{1,3,8}$ The basis for these associations is complex: effects of chronic systemic inflammation, psychosocial problems, and potential adverse effects of treatment may be important. ${ }^{1,3}$

The sample included 10 (12.3\%) atopic patients (asthma, rhinitis, or atopic dermatitis carriers); 25 (30.9\%) hypertensive patients; 18 (22.2\%) diabetic patients, and 14 (17.3\%) patients with dyslipidemias. Such results are compatible with studies that show that metabolic syndrome (MS), as a whole, and its isolated components have been associated with psoriasis (Table 2). ${ }^{13,8}$

Therefore, the present study identified a psoriasis patient population consisting mostly of dark-skinned adult males with low education and income levels who were sedentary and obese, with increased abdominal circumferences; who were ex-smokers; and who did not consume alcohol. These patients were diagnosed with psoriasis vulgaris, which mainly began on the scalp, hands and feet. In addition, many had some type of associated comorbidity and relatives who had psoriasis.

It is important to understand psoriasis patient profiles, considering the disease's high prevalence rate and the great impact on the patients' quality of life so that health promotion and intervention actions may be better targeted.]

\author{
MAILING ADDRESS: \\ Esther Bastos Palitot \\ Hospital Universitário Lauro Wanderley \\ Campus $I, s / n^{\circ}$ \\ Cidade Universitária \\ 58059-900 - João Pessoa - PB \\ Brazil \\ E-mail: estherpalitot@hotmail.com
}

How to cite this article: Cordeiro Júnior TGM, Andrade BDP, Palitot EB, Piuvezam MR, Mascarenhas SR. Profile of patients attending by a reference center, support and treatment for psoriasis patients at a university hospital. An Bras Dermatol. 2016;91(5):691-3. 